NBER WORKING PAPER SERIES

\title{
PUBLIC-PRIVATE INTERACTION AND \\ THE PRODUCTIVITY OF \\ PHARMACEUTICAL RESEARCH
}

\author{
Iain Cockburn \\ Rebecca Henderson \\ Working Paper 6018 \\ NATIONAL BUREAU OF ECONOMIC RESEARCH \\ 1050 Massachusetts Avenue \\ Cambridge, MA 02138 \\ April 1997
}

We gratefully acknowledge financial support by the Alfred P. Sloan Foundation through the NBER Project on Industrial Technology and Productivity, as well as by the UBC Entrepreneurship Research Alliance (SSHRC grant \# 412-93-0005). We would also like to express our appreciation to those firms and individuals who generously contributed data and time to the study, and to Gary Brackenridge and Nori Nadzri, who provided exceptional research assistance. Lynn Zucker and Michael Darby provided many helpful comments and suggestions. The usual disclaimers apply. This paper is part of NBER's research program in Productivity. Any opinions expressed are those of the authors and not those of the National Bureau of Economic Research.

(C) 1997 by Iain Cockburn and Rebecca Henderson. All rights reserved. Short sections of text, not to exceed two paragraphs, may be quoted without explicit permission provided that full credit, including $(\mathcal{C}$ notice, is given to the source. 
Public-Private Interaction and the Productivity

of Pharmaceutical Research

Iain Cockburn and Rebecca Henderson

NBER Working Paper No. 6018

April 1997

JEL Nos. H8, L2, L6, O3

Productivity

\section{ABSTRACT}

We examine the impact of publicly funded biomedical research on the in-house research of the for-profit pharmaceutical industry. Qualitative analysis of the history of the discovery and development of a sample of 21 significant drugs, and a program of interviews with senior managers and scientists reveals a complex and often bidirectional relationship between the public and private sectors of the industry, illustrating the difficulties inherent in estimating the rate of return to public support of basic research. This analysis also highlights the importance for private sector firms of maintaining close connections to the "upstream" scientific community, which requires them to make significant investments in doing in-house basic research and adopting appropriate internal incentives and procedures. We measure the extent and nature of this "connectedness" using data on coauthorship of scientific papers between pharmaceutical company scientists and publicly funded researchers. These measures are significantly correlated with firms' internal organization, as well as their research performance in drug discovery as measured by important patents per research dollar. The size of the estimated impact of "connectedness" to private research productivity implies a substantial return to public investments in basic research.

Iain Cockburn

Faculty of Commerce

University of British Columbia

2053 Main Mall

Vancouver, BC V6T $1 Z 2$

CANADA

and NBER

cockburn@nber.org
Rebecca Henderson

Sloan School of Management

Massachusetts Institute of Technology

E52-543

Cambridge, MA 02139

and NBER

RHENDERS@MIT.EDU 


\section{Introduction}

Economic debate on the role of publicly funded science begins with the observation that there is a substantial gap between social and private returns to $R \& D$, particularly in the case of "basic" research. Many researchers have identified externalities arising from the public good aspects of knowledge as the source of this gap (Nelson, 1959; Arrow, 1962), and the idea that the inability of profit-maximizing firms to appropriate the full economic returns from R\&D is likely to lead to under-investment in research relative to the social optimum remains an uncontroversial basis for substantial public support of R\&D in general, and basic scientific research in particular, in most developed economies (Mowery, 1983).

Efforts to measure the rate of return to public research have, however, been much more contentious -- and dogged by a variety of difficult practical and conceptual problems (Griliches, 1979; Jones and Williams, 1996). Though measuring the research output of the public sector and its impact on the rest of the economy presents enormous challenges, both quantitative and qualitative estimates suggest that the rate of return to basic research is probably quite high. Direct quantitative estimates place it on the order of 25-40\%, (Adams, 1990; Mansfield, 1991; Griliches, 1979, 1994), and studies of universityindustry relations have found a positive effect of university research on private sector R\&D (with the important caveat that in many industries firms appear to place a higher value on the education and training function of the university sector than its research output (Jaffe, 1989; Mansfield, 1991). At the same time case studies of specific technologies and government programs point to the critical role of public sector research in laying the foundation for technological advances that have later had enormous impact on the civilian economy (see for example David, Mowery, Steinmuller, 1992).

In this paper we examine the interface between for-profit and publicly-funded research in the pharmaceutical industry, one of the most science-intensive sectors of the economy and one where public support for research has been very substantial: between 1970 and 1995, for example, public funding in the US for health related research increased nearly $200 \%$ in real terms, to $\$ 8.8$ billion, or $36 \%$ of the 
non-defense Federal research budget, an amount roughly equal to the total research expenditure of all the U.S. pharmaceutical firms. This level of support is far from uncontroversial, however. While it seems clear that the industry's rapid rate of technological change and impressive economic performance rests on a foundation of long term publicly funded investments in basic science (Comroe and Dripps, 1976; Raiten and Berman, 1993; Maxwell and Eckhardt, 1990; Ward and Dranove, 1995), attributing specific tangible payoffs to these investments is difficult. Despite the huge acceleration in real research spending by both public and private sector institutions over the last 25 years, the rate of introduction of new drugs has remained approximately constant, and some observers have found the rate of improvement in such broad epidemiological measures of biomedical "output" such as mortality and morbidity disappointingly slow (Wurtman and Bettiker, 1994).

Definitively resolving these questions presents formidable problems of measurement and interpretation, as the qualitative results of this paper suggest. Using case histories of the discovery and development of 21 important drugs, together with interviews with senior managers and scientists at pharmaceutical companies and public sector institutions, we document the evolution of the complex relationship between publicly-funded and for-profit research in the industry over recent decades. The presence of very long lags between fundamental discoveries and consequent marketed products, and a high degree of mutual interaction between public and private sector researchers at all stages of the drug development process suggests that it is extremely hard to quantify the public sector's separate contribution to the industry's pool of knowledge capital, let alone identify causal links between these contributions and their subsequent economic impact. Rather, we focus here quite narrowly on the relationship between private sector firms' participation in "open science" and the productivity of their in house research to give an indirect estimate of the economic significance of publicly funded science.

Both our qualitative work and the results of prior research lead us to believe that "connectedness" to the community of open science is a key factor in driving a firm's ability to recognize and use upstream 
developments, and that it has a large impact on research productivity.' Gambardella $(1992,1995)$ showed that research productivity was correlated with publication rates for a sample of large pharmaceutical firms, and an important stream of work by Zucker, Darby and their collaborators on biotechnology firms has shown that both rates of firm founding and rates of new product introduction are a function of connections to "star" university scientists, suggesting that in this highly visible sector access to basic research may play a significant role in firms' ability to do more appropriable applied research and ultimately to produce marketable products (Zucker, Darby and Brewer, 1997; Zucker, Darby, and Armstrong, 1994). Our own prior research exploring the determinants of research productivity in the more conventional, "small molecule" segment of the pharmaceutical industry suggests that research productivity is highly correlated with the degree to which the firm has adopted the norms and incentive mechanisms of public science to manage their own, private, research (Henderson and Cockburn, 1994).

Here we interpret "connectedness" as capturing (albeit in a very limited way) the ability to access the common pool of useful knowledge generated by upstream public sector researchers. Variation across firms and over time in "connectedness" and in research performance allows us to estimate the private return to "connectedness", and thus place a tentative lower bound on the marginal return to upstream research without having to measure the output of upstream researchers directly.

We measure a pharmaceutical firm's "connectedness" to the public sector by counting coauthorships of scientific papers. We find significant differences across firms in the extent and nature of their coauthoring behavior. These differences are correlated with differences both in firms' internal incentive structures and methods of research organization and with differences in their research

\footnotetext{
${ }^{1}$ As Cohen and Levinthal, (1989) and others have noted, firms wishing to take advantage of research conducted in the private sector must invest in "absorpative capacity," or in a certain amount of science themselves. Here we wish to suggest that in the pharmceutical industry it may be necessary to move beyond this: while it is certainly necessary to invest in basic research inside the firm, we believe that it also necessary to be actively connected to the larger community. See also Rosenberg (1990).
} 
performance. While any estimate of this type must be treated with great caution, our results suggest that differences in the effectiveness with which a firm is accessing the upstream pool of knowledge correspond to differences in private sector research productivity of as much as $30-40 \%$.

This is clearly very much a lower bound estimate of the impact of public sector research, since by definition it excludes the impact of any publicly generated knowledge that can be costlessly accessed across the industry. Moreover translating it into an estimate of the economic rate of return to publicly funded research requires one to estimate the social rate of return to the output of the private sector, a formidably difficult proposition which lies beyond the scope of this paper.

Nevertheless we believe that these results have significant implications for public policy. They confirm that any attempt to measure the rate of return of publicly funded research must take account of the bi-directional nature and complex time structure of the information flow between the public and private sectors. But they also suggest that any such calculation should, ideally, also take account of the impact of public sector research on private sector productivity. Most importantly, perhaps, they suggest that the ways in which public research is conducted may be as important as the level of public funding. To the extent that efforts to realize a direct return on public investments in research lead to a weakening of the culture and incentives of "open science" the productivity of the whole system of biomedical research may suffer.

The paper begins a discussion of the 21 case histories that we have constructed and a description of the reciprocal nature of public private interaction in the industry as a foundation for the quantitative analysis. Section III discusses our qualitative evidence for the importance of public sector involvement on private sector productivity and section IV presents our quantitative results. The paper closes with a discussion of some of the implications of our results and of directions for further research.

\section{Case Histories: 21 Important Drugs}


In a detailed study of the discovery of 32 innovative pharmacodynamic ${ }^{2}$ drugs introduced prior to 1990, Maxwell and Eckhardt concluded that universities, government laboratories, non-profit research institutions and hospitals played a very significant role in drug discovery. They suggested that without these "nonindustrial" contributions "approximately $60 \%$ of the drugs would not have been discovered or would have had their discoveries markedly delayed" (Maxwell and Eckhardt, 1990).

As a first step in exploring the nature of public-private interaction in the pharmaceutical industry we began our research by expanding on Maxwell and Eckhardt's results. We constructed detailed case histories of 21 drugs identified by two leading industry experts as "having had the most impact upon therapeutic practice" between 1965 and 1992. Our sample includes 5 of the drugs (cyclosporine, nifedipine, captopril, cimetidine and propranolol) that Maxwell and Eckhardt, who used a similar criterion but focused on an earlier time period, included in their sample. Notice that this is a highly selective and not necessarily representative sample of new drugs introduced in this period, and that many potentially important drugs arising from more recent discoveries are still in development or have been just introduced. Nevertheless we believe that a focus on these drugs offers some intriguing insights into the role of the public sector in drug development and into some of the ways it has changed over time. The 21 drugs, and a brief outline of their history, are presented in Table (1) ${ }^{3}$ Obviously we can only baldly

\footnotetext{
${ }^{2}$ Where "pharmacodynamic" is used to designate drugs that are useful because of their effects on the functioning of the patient's systems as opposed to agents that have their effect because they selectively inhibit or destroy external agents such as infectious microorganisms.

${ }^{3}$ For purposes of general comparison we list a "date of key enabling discovery" for each drug. The choice of any particular event as the "key enabling discovery" is bound to be contentious, since in pharmaceuticals, as in many fields, discovery usually rests on a complex chain of interrelated events. In the case of drugs discovered through screening we give the date of first indication of activity in a screen. In the case of "mechanism" based drugs, we give the date of the first clear description of the mechanism. Dates for the third class are only broadly indicative, and all should be used carefully.
} 
summarize here the rich and fascinating stories of their discovery and development.

At first glance the table confirms a view of the world in which the primary role of the public sector is to provide fundamental insights in basic knowledge as a basis for drug discovery. Only 5 of these drugs, or $24 \%$, were developed with essentially no input from the public sector. This contrasts with Maxwell and Eckhardt's finding that $38 \%$ of their sample of older drugs were developed with no public sector input. Thus public sector research appears to have become more important over time, as one might expect given the increasing role of modern molecular biology in drug discovery. Notice, however, how old much of this research is. The publicly funded science on which many of these drugs rely was conducted in the forties and fifties. The only drugs in the sample which are directly based on "modern" research - on genetics and molecular biology - are AZT, acyclovir and the two "biotech" drugs erythropoietin (Epo) and interferon beta. ${ }^{4}$

In Table (1) the drugs are grouped into three classes according to the research strategy by which they were discovered: those discovered by "random screening", those discovered by "mechanism-based screening" and those discovered through fundamental scientific advances. Broadly speaking, the degree of reliance on the public sector for the initial insight increases across the three groups. The first group - drugs whose therapeutic potential were uncovered through "old fashioned" drug discovery i.e. through the random screening of large numbers of compounds against crude screens (animal models of disease, looking for "something new" in fermentation broths) - are those that were discovered with minimal initial input from the public sector. With the notable exceptions of foscarnet and tamoxifen, all of these

\footnotetext{
${ }^{4}$ We would hesitate to draw the conclusion, however, that modern research in molecular biology has had only limited effects on health outcomes. Given the lags apparent in the table between fundamental research and the discovery of new therapies we would suggest that the jury is still out as to this question. For example the recent introduction of the protease inhibitors, a new class of drugs designed to be used as therapies for AIDS, is persuasive evidence that the new biology may yield very significant benefits.
} 
drugs were discovered and first synthesized by private firms. ${ }^{5}$ This is not to imply that they were "easy" to find. The discovery of cyclosporine for example, called for considerable creativity and resourcefulness on the part of its discovers since cyclosporine was originally screened for antimicrobial activity, not for immunosuppressant properties (Borel, Kis and Beveridge, 1995). Similarly the discoveries of fluconazole, ketoconazole and nifedipine required much persistence and creativity on the part of the medicinal chemists who finally synthesized them (Maxwell and Eckhardt, 1990; Richardson et al., 1990).

In the case of the second and third groups of drugs the role of the public sector as the source of the initial enabling discovery is much more pronounced, and to this degree the drugs appear to reflect a more traditional mode of interaction between the public and private sectors. In the case of the second group of drugs presented in the table, those discovered principally through the technology of "mechanism based screening" ${ }^{\prime 6}$ the age of much of the public sector research involved meant that in principle one might expect there to have been relatively little contact between the public and private sectors. In practice, however, the desire to keep "up to date" in the search for compounds that might inhibit

${ }^{5}$ Foscarnet and tamoxifen illustrate a rather "odd" property of publicly funded research in this industry: the fact that some fraction of public funds are devoted, explicitly, to the discovery of new therapeutic agents rather than to the generation of basic knowledge. Foscarnet was synthesized by a European chemist working in a publicly funded lab. Tamoxifen was discovered through the National Cancer Institute's screening program. AZT's antiviral properties were also discovered through a screening program conducted by the NIH.

"In "random" screening researcher evaluate the therapeutic utility of a compound by putting it into an animal or tissue screen. For example they might seek compounds for the treatment of hypertension by injecting the compound into hypertensive rats or by exploring its impact on cardiac tissue. In "mechanism based" screening researchers use their detailed knowledge of the root cause of certain physiological conditions to search for compounds. In the case of hypertension, for example, they might explore the degree to which the compound inhibits the production of renin, a key step in the pathway that can lead to elevated blood pressure. 
particular enzymes or block particular receptors led several of the private sector researchers involved to keep in close contact with colleagues exploring the mechanism in the public sector. Ondetti and Cushman, for example, the two scientists jointly responsible for the discovery of captopril, kept in close contact with researchers in Brazil and England who were exploring the impact of various peptides derived from snake venom on the regulation of blood pressure (Ondetti, Rubin and Cushman, 1977). Similarly the work of Sir James Black and his colleagues in the discovery of propranolol sprung directly from research conducted in the public sector into the adrenergic effects of dichloroisoproterenol (DCI) (Maxwell and Eckhardt, 1990).

A critical reliance on the public sector for fundamental research is most immediately obvious in the case of the third group of drugs, three of which - Epo, Interferon and AZT - spring directly from modern research in genetics, and the fourth of which, cisplatin, was discovered and developed entirely in the public sector. Epo and interferon are proteins produced by the body itself to regulate blood growth (Epo) and fight infection (interferon). Their function had been slowly elucidated over many years through fundamental research conducted by a wide variety of researchers. Their production is a triumph of modern molecular biology and the tools of DNA cloning and fermentation.

The interaction between public and private sectors in the case of the discovery of AZT are so tight that the attribution of the discovery of the drug is a matter of great debate. AZT was first synthesized by a public sector researcher looking for activity against cancer. It then languished for many years in the library of compounds maintained by antiviral researchers at Burroughs Wellcome. Its value in prolonging the life of some AIDS patients only became apparent when BW sent it, along with a dozen other candidate compounds, for testing against a screen developed at NIH (Nussbaum, 1990).

Thus far we have discussed the role of classical "scientific" knowledge in the generation of new drugs. The development of the majority of these drugs, however, also relied heavily on the public sector for clinical, or applied knowledge. In several cases, publicly funded work in epidemiology was of critical 
importance in motivating firms to search for particular therapies. For example, we now take for granted that reductions in even moderately elevated blood pressure can have a positive effects on health: fifty years ago this was not at all clear, and without the large scale studies funded by the NIH into the long term health implications outcomes of high blood pressure it is unlikely that private sector researchers would have sought so aggressively for drugs to alleviate hypertension (Gilman et al., 1993). This kind of agenda-setting research was important to the decision to search for nearly all of the drugs in the table. While in general the results of these kinds of studies are broadly disseminated and are rarely the cause for the kinds of detailed interaction between public and private sectors that are the focus of this paper, this is not always the case. In the case of lovastatin, for example, the decision to pursue the drug was heavily influenced by a couple of key clinicians who were monitoring patients with severe hyperlipidemia who were not responding well to existing therapies. Since a sizeable body of medical opinion at the time held that diet and exercise were key to reductions in cholesterol levels, Merck's decision can thus be viewed as the result of precisely the kind of personal, information rich exchanges that we attempt to capture in the quantitative work below.

Publicly funded clinical knowledge was also critically important in the design of several of the trials that were needed to test the safety and efficacy of any new drug. For example when Merck sought to test the efficacy of finasteride (Proscar), the first drug targeted specifically at BPH (Benign Prostatic Hypertrophy), the firm had to work very closely with specialists in the disease to design clinical trials that would generate useful information (Rittmaster, 1994).

Publicly funded clinical research is also extremely important as a source of insight into new uses for existing drugs. This is most dramatically illustrated by the fact that many of the most important advances in drug treatment in the last 25 years are not listed in our table as they have resulted from the discovery that many "old" drugs can be very effective in hitherto unsuspected applications. For example the use of aspirin for the prevention of heart attacks, the use of antiepileptics for the treatment of bipolar 
disease and the use of antibiotics in the treatment of peptic ulcers are all examples of this kind of advance (See Wurtman and Bettiker, 1996; Table 7.4 in Gannelin, 1993).

In the case of drugs that are "off patent," the vast majority of these advances originate in work in the clinic that is funded either by the public sector or by health care consumers. When a drug is still covered by patent protection, the situation is more complicated. While any qualified physician can prescribe any drug for any condition he or she sees fit, pharmaceutical firms are forbidden to advertise or promote any use of their product that has not been formally approved by the FDA. This sometimes leads to rather strange situations. Cisplatin, for example, is only formally approved for treatment of ovarian cancer, although it is well known to be immensely useful in the treatment of testicular cancer (Gilman et al., 1993). Bristol-Myers Squibb, who hold manufacturing and distribution rights for the drug, cannot mention cisplatin's use in the treatment of testicular cancer in any of their materials, and cannot fund research into cisplatin's efficacy as a testicular cancer agent without filing an IND (an Investigational New Drug Application - a formal request to test the efficacy of a drug in new disease in humans) with the FDA. Any qualified cancer specialist is under no such restraint and may explore Cisplatin's efficacy in any condition he or she sees fit. Thus the pharmaceutical firms are forbidden to fund research into offlabel indications - even forbidden to publicize that such research is going on - and as a result clearly have an enormous incentive to stay closely connected to leading publicly funded researchers who might be conducting such work. ${ }^{7}$

Thus in general the private sector draws from the public throughout the life of a drug: as a source of fundamental knowledge that might lay the groundwork for new drugs, as a source of clinical

${ }^{7}$ If something seems particularly promising the manufacturer can then file an IND and fund large scale clinical trials in the hope of obtaining another NDA. When early work suggested that the ACE inhibitors might be as useful in the treatment of heart failure as in the treatment of hypertension, for example, both Merck and Bristol-Myers Squibb funded large scale trials to document the effect. 
knowledge for the design of tests for drugs once they have been discovered and as a source of clinical knowledge about additional indications for drugs once they have been approved.

The impact of the private sector on the public is similarly multifaceted and also extends across the life cycle of a drug. Major drug discoveries often have very significant implications for research of the most "basic" kind. The availability of a new therapeutic agent permits researchers to explore the ways in which the body works - often at the cellular level - in much more detail than is possible before. For example the discovery of cyclosporine opened up a wide range of avenues to basic research on the immune system, and the discovery and use of nifedipine focused attention on the role of calcium transportation in cardiac and other tissues (Maxwell and Eckhardt, 1990). Perhaps the most well known example of this effect is that of the role of lovastatin (Mevacor) in the research that led to Brown and Goldstein's ultimately being awarded a Nobel prize for their work elucidating the ways in which cholesterol is metabolized by the cell.

Lovastatin was discovered by researchers at Merck who were screening compounds for inhibition of a key enzyme involved in the production of cholesterol. They were building on a very long history of research in the regulation and metabolism of cholesterol, but specifically on a sequence of papers by Siperstein, Shapiro, Rodwell, Heller and Gould that explored the role of $\beta$-hydroxy- $\beta$-methylglutaryl Coenzyme A reductase in the regulation of cholesterol and refined experimental methods for its isolation and purification (Shapiro and Rodwell, 1971; Siperstein and Guest, 1959). This work was broadly known in the research community, and Merck does not appear to have relied on any immediate scientific input to guide its discovery. Once lovastatin was available, however, it provided researchers with a powerful tool for understanding the regulation of cholesterol synthesis within the cell. In particular, it appears that the ability to use lovastatin was of significant help to Brown and Goldstein, researchers affiliated with the University of Texas, in their path breaking research into the structure and function of the LDL receptor (Brown and Goldstein, 1986). Both Brown and Goldstein were working as consultants to Merck 
at the time of lovastatin's discovery, but their scientific work appears to have had little immediate impact on Merck's research strategy or choice of screen.

Figure (1) illustrates the impact that the discovery of a new drug can have on fundamental science. The graph plots the number of papers published listing the word "fluoxetine" (Prozac) in their title appearing in the Medline ${ }^{\mathrm{TM}}$ database, divided into "development" versus "discovery" according to whether they treat with the effect of the drug on human subjects or not. While there are a very large number of "development" papers published after each drug is approved, as one would expect, there are also a large number of discovery - or research — papers published. The same pattern is apparent in data for a number of other compounds we have looked at, such as lovastatin.

The history of these 21 drugs highlights the complex, iterative nature of the interaction between public and private researchers in the generation of new drugs. Private researchers drew heavily on publicly funded "basic" knowledge. Publicly funded researchers also benefitted from privately funded research as new drugs offered them new tools for understanding human physiology and molecular biology. Private firms also relied heavily on publicly generated clinical knowledge, and in turn contributed much to publicly funded clinicians.

These kinds of complex interactions continue to be characteristic of much drug research and development today. Private sector researchers continue to work closely with public sector researchers in the hope of gleaning new knowledge that may be of value in the search for new therapies. Public sector researchers continue to find private sector work useful. It is not only major new breakthroughs that offer insights: many compounds identified or synthesized by pharmaceutical companies that are never approved as drugs nevertheless yield insight into human physiology and biochemistry that prove quite valuable to public sector researchers. Thus our qualitative research provides some insights into one of the most initially puzzling feature of our quantitative data: that publicly funded researchers are willing to coauthor extensively with private sector researchers. 


\section{The Organization of Pharmaceutical Research}

In previous work we have shown that pharmaceutical firms differ significantly in the ways in which they manage research and that these differences have important implications for their research productivity (Henderson and Cockburn, 1994). Extensive interviews with senior pharmaceutical company scientists and managers have given us a number of insights into the nature of these differences, and in particular into the contribution made by the norms and institutions of publicly funded science in developing and sustaining them.

Research conducted in the public sector is managed and rewarded quite differently from work conducted in the private sector. Sociologists and historians of science, and a growing body of work in economics, have identified a distinctive set of incentives used within the community of "open science" to allocate resources and reward individuals (Merton, 1973; Dasgupta and David, 1987, 1994; Stephan, 1995). Public sector researchers are concerned with priority. Recognition and rewards go to those that are recognized by the scientific community as having been the first to have made any particular discovery. Since priority is established by publication, public sector research is characterized by the rapid publication of key ideas and a dense network of communication across key researchers (Crane, 1972; Merton, 1973). Research undertaken in the private sector, in contrast, is believed to be shaped by the need to appropriate private returns from new knowledge, which leads firms to focus on applied research and to attempt to restrict communication of results. Private sector researchers are thus much more likely to be rewarded on the basis of their contribution to the financial health of the firm rather than on the basis of their contribution to scientific knowledge (Dasgupta and David, 1994).

These different incentive regimes are associated, perhaps not surprisingly, with quite different outcomes. A focus on priority appears to be particularly conducive to the rapid advance of scientific knowledge since it rewards the rapid communication of new ideas across the community of relevant researchers. A focus on appropriability, in contrast, is particularly conducive to the translation of 
scientific insight into commercial products.

Prior to about 1980 this distinction between public and private research was a reasonable characterization of the way in which research was managed in the pharmaceutical industry. Private firms worked closely with public researchers to ensure that they were taking advantage of public knowledge. They also sponsored research at universities, hosted conferences and hired university graduates. But within the firm, research was managed very much along prototypically "private" lines. Researchers were rewarded on the basis of their contribution to the firm: on the basis of the number of promising compounds that they had synthesized, for example. Publication was viewed as a distraction or a luxury. In the words of one research director whose research operation was still being managed along these lines in 1992:

"why should I encourage my guys to publish? Writing up a paper enhances their resume, but what does it do for me? That's time that could have been spent looking for drugs. "8 As long as the discovery of new drugs was a relatively straightforward process rooted largely in random screening this mode of organization appears to have been quite effective. However as the rate of scientific advance in the biomedical sector increased over the course of the 1970 s, several pharmaceutical firms gradually moved to a reliance on the public rank hierarchy as a monitoring mechanism for their research groups. They began to actively encourage publication and to hire researchers at the leading edge of their fields with the promise that they would reward them to continue doing cutting edge scientific research.

Promoting researchers on the basis of their standing in the scientific community has a number of beneficial impacts on research productivity. It allows the firm to monitor and reward researchers at relatively low cost. Since monitoring researchers in private organizations is notoriously costly, this is no small benefit (Aoki, 1990). It also forces researchers to publish and to remain in close touch with the state of knowledge in their field, which is important if the firm is to take advantage of scientific advances

\footnotetext{
${ }^{8}$ To preserve the confidentiality of interviewees we cannot reveal their identities or employers.
} 
as they arise. Lastly it acts as a powerful recruiting tool, since the highest quality scientists in a field are often reluctant to work for private firms if they will not be able to publish and thus maintain their personal scientific reputations.

Our respondents continually stressed the importance of publication and of "playing the priority game" to modern pharmaceutical research. While publication yields straightforward benefits in terms of increased absorptive capacity through its role as a signal of the availability of important information, it is also seen as an important activity in its own right. In the words of one scientist:

"I insist on my team publishing. It takes time, its a nuisance, but it is the only way of checking that one is doing really good science. Its so easy to become complacent..."

However as time progressed it became clear to several firms that the use of the public rank hierarchy as an incentive system was not, in itself, enough to ensure productive research. Firms that stressed publication and leading edge science "too much" gradually developed research groups that were much more like universities than anything else - and that shared the university's failure to be able to produce an actual, commercial product. They generated papers, but no drugs.

Thus several firms started to leverage their use of the public rank hierarchy with another mechanism: with the use of peer dominated committees to allocate resources across projects. When these committees worked well they were an enormous source of strength, forcing the dense exchange of information across the firm and allowing for the rapid identification (and funding) of promising new opportunities (Henderson, 1994). But these committees only worked well when they were characterized by the full and free exchange of information - when they were "high conflict" but equally "high respect" encounters. Such encounters appear to have been much easier to sustain in firms that reward researchers on the basis of their standing in the larger community and that in consequence employ relatively high status individuals. In the words of one research director:

"The fact that I'm fairly well known in my field (he was a widely published, highly regarded researcher who also held a position as an associate professor at a major 
university) means that I don't take attacks on my group as personal attacks. It also means that I'm not afraid to point out what I regard as scientific flaws with work done elsewhere in the firm. We can fight science with science, and when we come to debate priorities we take each other's judgement seriously."

In summary, then, the existence of a vibrant public sector, its interest in working with private sector researchers and its importance to drug research, allows private firms to create within the firm many of the mechanisms that other researchers have observed are characteristic of public sector science. These in turn both allow these firms to access public sector research effectively and to sustain a level of flexibility and responsiveness that gives them a significant edge over their rivals. ${ }^{9}$

\section{Quantitative evidence on public-private interaction}

We attempt to measure differences in the success with which private firms can take advantage of publicly generated knowledge capital by examining the publication patterns of pharmaceutical company scientists, in particular their coauthorship of papers with researchers working in other organizations. As prior research has established, pharmaceutical companies publish heavily, with annual counts of papers comparable to, and sometimes exceeding, the output of similarly sized universities and research institutes (Hicks, 1995). Publication counts are an important indicator of research activity, particularly investment in "absorptive capacity" (Gambardella (1992, 1995; Koenig, 1982). But they are relatively uninformative about interaction between researchers at different institutions, in the sense of sustained, direct, and meaningful intellectual collaboration. Since our qualitative work suggests that it is not simply publication that reshapes private sector problem solving but participation in the intellectual life of the wider scientific community, a focus on interactions is particularly important.

\footnotetext{
${ }^{9}$ The question of why these mechanisms have been differentially adopted across the industry is a fascinating one that we explore in a related paper, Cockburn and Henderson (1996).
} 
Following pioneering work by Zucker, Darby and their collaborators we focus here on coauthorship of papers as evidence of this type of interaction (See Zucker and Darby, 1995; Zucker, Darby and Brewer, 1997; Zucker, Darby and Armstrong, 1994), and Liebeskind, Oliver, Zucker, and Brewer, 1995). While Zucker, Darby and their collaborators focused on biotechnology, and on the technology of gene sequencing in particular, we focus on the conventional or "small molecule" sector of the industry that is dominated by the major pharmaceutical firms.

Another approach would be to study cross-citation. It would be interesting, for example, to see whether private sector scientists preferentially cite public sector researchers and vice versa. Citation patterns have been used very fruitfully to trace interaction among researchers and across organizational boundaries, and to identify research communities (See, for example, Penan (1996) and Narin and Olivastro (1992)). However analysis of citations presents a number of difficulties. Citation is often highly ritualized, occurs with variable and often very long lags, and may represent negative as well as positive acknowledgement of previous research. Furthermore, as is often pointed out, citation in the age of the wordprocessor and computerized databases is extremely cheap and easy. By contrast, as many researchers can testify from personal experience, joint authorship is costly in terms of effort as well as other resources. In order to be willing to collaborate on writing a paper all of the authors must be willing to incur these costs, which makes an instance of coauthorship a very different datum from a citation ${ }^{10}$ ".

We believe that coauthorship also evidences a qualitatively different kind of interaction than does citation. Joint authorship often reflects joint research, which is an important opportunity for the exchange

${ }^{10}$ We make no claims here as to the size of these costs, and particularly to symmetry across authors.

"Analysis of citations also presents some very serious practical difficulties and resource requirements for the kind of analysis we perform in this paper: without better access to machine-readable source data, tracking down the institutional affiliations of all of the authors of the 20 papers referenced by each of the 68,000 papers under consideration is a formidable and very expensive proposition. 
of tacit knowledge. By contrast citation may be seen as an acknowledgement of the exchange of codified knowledge. Citation also refers to old knowledge, whereas coauthorship reflects generation and exchange of new or current knowledge. We note also that citation takes typically takes place impersonally, and can be done at a distance, whereas (notwithstanding the internet) joint authorship typically entails face-to-face interaction. Most significantly, we see coauthorship as evidence of opportunities for extensive discussion, debate, exchange of ideas, and joint problem solving: something much more than reading the journals., and something that represents a much more significant investment on the part of the firm.

Naturally there are difficulties with this interpretation. Clearly much important interaction of this type takes place at arms length, or otherwise outside the realm of joint authorship of papers: researchers read each others work, correspond informally, listen to conference presentations, serve on professional committees together etc. etc. Coauthorship may also reflect a variety of things other than exchange of information and joint problem solving. It may be offered as a quid pro quo for supplying information or resources such as money or research materials such as reagents or cell cultures. Coauthorship is also an important means of resolving disputes about priority. It may also serve as a way to acknowledge of intellectual debts (for example to a thesis advisor or other mentor). As is well known, it is fairly common in physical and biological sciences to list Laboratory Directors or other senior project leaders as authors on papers which they may have had very little direct involvement in writing. Finally, the presence of some authors on the front page of a paper may simply reflect efforts by the "real" authors to attain legitimacy, or admission to networks of other researchers. ${ }^{12}$

12 Several readers of earlier drafts of this paper have disagreed with our interpretation of "coauthorship", suggesting that coauthorship may reflect simple acknowledgement for favors received. For example, they suggest, a university lab may include an industry scientist on a paper when the pharmaceutical firm has done no more than provide the university group with an interesting compound. The interviews that we have conducted with both researchers in both the public and private sector, however, lead us to believe that even these kinds of interaction are characterized by a quite rich exchange 
Notwithstanding these issues, we proceed on the assumption that coauthorships represent evidence of a significant investment on the part of the firm in developing connection to publicly funded research. This interpretation is consistent with our interview data, and moreover coauthorships have the virtue of being a consistently observable quantitative measure.

\section{Data Sources and Methods}

We collected bibliographic information on every paper published in the journals indexed in the Institute for Scientific Information's Science Citation Index between 1980 and 1994 for which at least one author's address was at one of a sample of twenty major research-oriented pharmaceutical firms. (We restricted our attention to this 15 year period simply for reasons of practicality.) This sample comprises the ten firms which we have studied in prior work, and for which we have very detailed data on their research performance, plus a further ten informally selected to capture the industry's leading R\&D performers and to obtain world-wide geographical representation. Obviously, these firms do not constitute a random sample, but we believe them to be reasonably representative of the industry as a whole. ${ }^{13}$ For purposes of comparison we also repeated the data collection effort for the National Institutes of Health (NIH).

As in Zucker, Darby, and Brewer (1997) (and related papers) we use authors' mailing addresses to identify collaboration across institutional boundaries. We measure instances of "coauthorship" by counting the number of difference addresses listed by Science Citation Index for each paper. This does not exactly correspond to coauthorship in the usual sense of the word, since the number of addresses on each paper does not necessarily equal the number of authors. For the 20 firms in the sample, there were on average 1.86 addresses per paper and 4.4 authors per paper. This is because Science Citation Index

of scientific knowledge.

${ }_{13}$ Table 4 lists the sample of firms. 
only records a maximum of six distinct addresses per paper, while as many as 27 authors may be listed, and identical addresses are not repeated. Though more than $50 \%$ of the papers in the sample have only one address listed, and these averages are skewed by the $4.5 \%$ of papers which have 10 more authors, this means that these counts of "coauthorship" should be more strictly interpreted as instances of institutional collaboration rather contact than coauthorship by individuals.

To trace interaction across different types organizations, we then classify each address according to its "TYPE": SELF, UNIVERSITY, NIH, PUBLIC, PRIVATE, NONPROFIT, HOSPITAL, and a residual category of UNCLASSIFIED. Because this procedure drives much of our analysis, it is worth describing in some detail. Table (2) gives a brief definition of each TYPE, and some examples of organizations which appear most frequently in the data set. We start by searching Science Citation Index for all papers listing our 20 firms (and obvious permutations and variations of their names). Papers for which the only addresses listed are for one of these firms (or their divisions or subsidiaries) are classified as SELF. UNIVERSITY addresses are self-explanatory (note though that this classification includes medical schools). NIH is an address at any of the National Institutes of Health. The PUBLIC category comprises government affiliated organizations such as National Laboratories, Departments of Public Health, government departments and ministries, national research organizations etc. HOSPITAL contains hospitals, clinics, community health centers, HMOs, disease treatment centers etc. NONPROFIT is a category made up of research centers, foundations, institutes and other not-for-profit but not governmentaffiliated organizations. PRIVATE comprises for-profit private sector organizations, principally pharmaceutical and biomedical firms. Organizations which we were unable to classify are given the designation UNCLASSIFIED.

An example may be helpful. Table (3) reproduces salient information from a sample record from Science Citation Index, one of more than 4,700 that would be found by searching for papers by scientists employed by Eli Lilly. The record for this paper lists five authors, and three addresses, and we interpret 
it as two "coauthorships" between Eli Lilly and other organizations: one UNIVERSITY coauthorship with the University of Rochester, and one UNIVERSITY coauthorship with Okayama University. A record with four authors and three Eli Lilly addresses (e.g. Lilly Research La Jolla, Eli Lilly GMBH Homburg, and Eli Lilly Corporate Center Indianapolis) is treated as one instance of coauthorship with SELF.

It is important to note that these definitions are necessarily somewhat arbitrary, and that it is not always clear to which category some organizations belong. For example it is difficult to draw a clear distinction between teaching hospitals affiliated with medical schools (classified as UNIVERSITY) and non-teaching hospitals (classified as HOSPITAL), or to classify some institutions as either NONPROFIT or PUBLIC. Nonetheless, we were able to classify almost all of the more than 14,000 distinct addresses in the data, with only 1044 falling into the residual category of UNCLASSIFIED. Weighted by their frequency of occurrence in the data, these UNCLASSIFIED organizations constitute less than $1.5 \%$ of the observations. We are reasonably confident about the success of the classification procedure. Due to the very large number of observations (and organizations) tinkering with the definition of the categories has little impact on the results: the great majority of the observations are attributable to institutions whose TYPE is unambiguous.

We make no attempt here to control for the quality of each publication. Weighting instances of coauthorship by the ranking of the journal, or by the number of citations the paper subsequently receives, may well be worth doing in further work.

For ten of these 20 firms, these data on publications and coauthorship are supplemented by an extensive data set collected for previous studies from confidential internal company records. This data set extends from 1965 to 1990 and includes discovery and development expenditures matched to a variety of measures of output including important patents, INDs, NDAs, sales and market share, as well as variables constructed from interview data which capture the nature of the firms' decision-making procedures and incentive systems. These data are described in more detail in previous work (Cockburn 
and Henderson, 1994; Henderson and Cockburn, 1994, 1996). Although for reasons of confidentiality we cannot identify these firms, we believe that they are not markedly unrepresentative of the industry in terms of size, or of technical and commercial performance.

\section{Analysis}

Publication activity of the private sector

The descriptive statistics for our data on publication and coauthoring activity provide some interesting evidence on the scale and nature of public-private interaction. The first point to be made is that private sector scientists publish extensively. For these twenty firms alone, our working data set contains 68,186 papers published during the 15 year sample period: on average just over 227 papers per firm per year. These statistics conceal considerable variation across firms and over time: publications rates range from a minimum of only 2 per year, to a maximum of 958 per year. As Table (4) indicates, the rate of publication has been rising steeply over time, from an average of 150 papers per firm per year in 1980 to more than 350 per firm per year in $1994 .^{14}$

These papers appear in leading journals: among the most frequent outlets for these papers are Abstracts of Papers of the American Chemical Society, Federation Proceedings, the Journal of Medicinal Chemistry, the Journal of Antibiotics, and the Journal of Biological Chemistry. The list of top 50 journal outlets for the twenty firms is similar to that for the 81,574 "public-sector" papers in our NIH sample (obtained by searching for "NIH" in Science Citation Index instead of "Company X") with some interesting exceptions. There are more pharmacology journals in the top 50 list for the 20 firms, which

\footnotetext{
${ }^{14}$ Care must be taken in interpreting these trends, both because we cannot normalize by the number of scientists employed by each firm, and because the journal set covered by Science Citation Index changes over time.
} 
is perhaps to be expected. But while prestigious journals with a clinical orientation ${ }^{15}$, such as the Journal of the American Medical Association and the New England Journal of Medicine are among the most frequent outlets for NIH researchers (JAMA is ranked 15th and the New England Journal of Medicine 12th) they appear very far down the list for the 20 firms (140th and 177 th respectively.) This reflects one of the puzzles in these data: pharmaceutical company scientists appear to publish relatively few clinical papers. Searching the Medline database, which covers a somewhat different and smaller journal set but is exhaustively indexed, reveals relatively few papers where keywords for clinical research such as "HUMAN SUBJECTS" appear in the index fields and a pharmaceutical firm is listed as an affiliation of one of the authors. To the extent that private sector organizations can be expected to publish less the closer the research is to the marketplace, this makes economic sense. But we hesitate to classify clinical research as being necessarily hard-to-appropriate or "pre-competitive" and we continue to investigate this issue. One factor responsible for this phenomenon may be that editorial policy at some top journals restricts publication of studies whose authors may get immediate financial rewards from the results.

Turning to the publication behavior of individual researchers, we obtain results similar to many previous bibliometric studies. By using the papers with only one address, we were able to compile a list of researchers affiliated with one of the 20 firms, and then to count the number of times these individuals appeared as an author on one of the papers in the dataset. This procedure excludes individuals who only appear as authors on papers with multiple addresses, but this is a fairly small number for most of the firms. The distribution of annual publication counts for these researchers is highly skewed to the left: of our 48,525 observations on annual publication rates, $56 \%$ are at one paper per year. Just as in public sector research organizations, in some firms an elite of leading researchers publishes very heavily, at a

${ }^{15}$ Great care should be taken in labelling journals as "basic" or "applied", or "clinical" versus "laboratory", as their content typically spans the whole spectrum of basic and applied research, as well as many different disciplines. 
rate as high as 20 papers per year. Though there is substantial variation across firms and over time, it is nonetheless interesting that these private sector institutions exhibit the heavily skewed distribution of publications per researcher and disproportionate share of "star" researchers characteristic of publicly funded research communities.

\section{Patterns of Coauthorship}

Our "coauthorship" measure of interaction with researchers outside the firm reveals extensive collaborative activity. Of the 68,186 papers in the sample, $49.6 \%$ involved collaborations across the boundaries of the 20 firms. Moving to the metric of "coauthorships" rather than publication counts, we observe a total 89,280 instances of "coauthorship" for our sample of 20 firms, counting papers authored entirely within the firm as one instance of coauthorship with SELF.

Breaking these "coauthorships" down by the TYPE of coauthoring institution, reveals some interesting information. For the sample as a whole, SELF accounts for $43 \%$ of all coauthorships, with UNIVERSITY being by far the largest external category at $34 \%$ of the total. HOSPITALs were just under $10 \%$ of the total, other PRIVATE institutions 5\%, and NONPROFIT and PUBLIC accounted for a further $3 \%$ each. Curiously, NIH accounted for only $1 \%$ of the total. This appears not to be an artifact of the sample: the breakdown of over 112,000 such "coauthorships" in our NIH sample is not markedly different, with the great majority of coauthorships being with SELF and universities, and less than $4 \%$ with private sector institutions. While many university researchers are supported by NIH grants, and thus should perhaps be re-classified as "NIH", it is still interesting that linkages between the private sector and the NIH are via this indirect channel.

Some interesting trends over time are apparent, both in amount of coauthoring activity and in the mix across different types of institutions. (See Tables (4 and 5)) Both publication rates and coauthoring rose sharply over the 15 year period, with coauthoring rising significantly faster. The number of 
coauthorships per paper rose from 1.13 in 1980 to 1.42 in 1994 . Over these 15 years the fraction of UNIVERSITY coauthorships rose steadily from $24 \%$ of the total to $38 \%$, largely at the expense of SELF. The fraction of coauthorships with other private sector organizations also rose, but no significant trends in the aggregate share of the other types of coauthorships are apparent.

\section{Links to Public Sector Research and Private Sector Research Productivity}

These data on "coauthoring" document significant linkages between private sector research and "upstream" public sector activity. But the import of such linkages is unclear. Does more participation in the wider scientific community through publication or coauthoring give a private sector firm a relative advantage in conducting research? In prior work we found substantial and sustained variation in the research performance of pharmaceutical firms, even after controlling at a very detailed level for economies of scale and scope in the research laboratory, competitive activity, differences in the composition of the research portfolio across areas technological opportunity and "horizontal spillovers" within and between firms. As suggested above, we believe that these performance differentials may be driven to a significant degree by differences in firms' linkages to the "upstream" research community.

As Table (5) indicates, this sample of firms shows marked differences in publication and coauthoring behavior, and the types of institutions they collaborate with. The average fraction of coauthorships with SELF ranges across firms from $31 \%$ to $68 \%$, with HOSPITALs from less than $1 \%$ to $14 \%$, and with other PRIVATE sector firms from $2 \%$ to $9 \%$. There is also substantial variation across firms in these evolution of these variables over time. Formal tests strongly reject homogeneity across firms in the distribution of their coauthorships over TYPE, even after controlling for a time trend. $\left(\chi_{133}^{2}=5141\right)$

The question then arises as to whether these differences in coauthoring activity are related to firms' research performance. For a subset of 10 firms, we are able to match the coauthoring data to our 
data on their research performance and other measurable characteristics of their research programs. We then look for correlation with the extent and nature of coauthoring activity in two ways, firstly by establishing a statistical link between firms' choice of type of coauthor and the ways in which they organize the research function, and secondly by testing for the impact of these choices (as well as publication-based measures of the degree to which firms employ the incentive mechanisms of the public sector) upon research performance.

In prior work we constructed a number of measures of these ten firms' internal incentive systems and decision-making procedures from structured interviews. The extent to which each firm was "propublication", in the sense of using publication in the open literature or an individual's reputation and standing in the wider scientific community as a basis for promotion and compensation was rated on a 5point Likert scale. A similar variable was constructed to measure the extent to which firms use a "dictator" to allocate research resources versus a peer-review committee system. These ratings vary over time as well as across firms. ${ }^{16}$ Table (6) presents results from using these two variables, as well as a time trend and a measure of the scale of the firm's research effort, to model the choice of TYPE of coauthor in a multinomial logit framework. (For convenience, NIH is subsumed in PUBLIC, and UNCLASSIFIED is dropped.) The first panel reports the estimated coefficients of the model, the second panel gives the estimated marginal effects upon the probability of choosing each category.

Encouragingly, we find effects consistent with our hypothesis that variation across firms and over time in coauthoring choices is related systematically to differences in the ways in which they organize their research function. Conditional on publishing, being more "Pro-publication" has a negative effect on the probability of coauthoring only with researchers in the same firm, and a positive effect on the probability of coauthoring with external institutions. The largest such effect is on the probability of

\footnotetext{
${ }^{16}$ See Henderson and Cockburn (1994) for more detail on the interview process and the construction of these variables.
} 
coauthoring with a university. Increasing use of a "dictator" increases the likelihood of coauthorship with SELF, and decreases the likelihood of publishing with external coauthors. Goodness-of-fit measures are hard to interpret in this kind of model, but we note that comparing the estimated model and the restricted model with constants gives a likelihood ratio test statistic of $\chi_{20}^{2}=660.7$, strongly rejecting the hypothesis that the estimated coefficients are all zero. Obviously we can infer nothing about causality from these results, but they do suggest a meaningful link between coauthoring activity and firms choices about managing research.

We turn therefore to the relationship between research performance and linkages to the public sector. Tables (7) and (8) present results from regressing a simple measure of research productivity on to variables derived from the bibliometric data, and other controls for factors that our previous work has shown to be related to research productivity such as the scale and scope of the research portfolio. Research productivity is measured by "important patents per research dollar", where "importance" is defined by the patent being granted in at least two out of three major world markets - Japan, the US and Europe - and research is expenditure on the "discovery" phase of R\&D, and excludes clinical development. ${ }^{17}$ The fraction of coauthorships in each year with universities is a measure of the degree to which the firm is linked to the public sector. The fraction of the firm's publications in each year attributable to the top $10 \%$ of its scientists (ranked by number of publications) is a proxy for the presence of a "star" system within the firm, a key aspect of the incentive system of the public sector. Total publications per research dollar per year can be thought of a measure of investment in absorptive capacity. Firm dummies and a time trend are also included as control variables. In Table (7) the coefficient on fraction of coauthorships with universities is positive and significant in five of the six regressions reported, even controlling for firm fixed effects, a time trend, "propensity to publish", and other determinants of research productivity. (In column (6) of the table we include both a full set of

\footnotetext{
${ }^{17}$ See Henderson and Cockburn (1996) for details on the sources and construction of these data.
} 
control variables and firm dummies, which effectively "kills" the regression because of multicollinearity.) We interpret this as evidence that the nature of linkages with public sector research may have a significant effect on private sector research productivity, above and beyond the amount of publishing activity.

Presence of a "star" system also correlates positively and significantly with research productivity in the regressions reported in Table (8). As before, this result is robust to including papers per research dollar as a measure of the amount of interaction with the public sector, as well as firm fixed effects. The result weakens as we include more control variables: the sample is quite small and there is insufficient independent variation in the explanatory variables leading to multicollinearity and unstable coefficients. We see this result as being consistent with the hypothesis that using the rank hierarchy incentives of the public sector improves the quality of private sector research.

We hesitate to over-interpret these results: confounding with aggregate time trends, the small sample imposed by incomplete data, difficulties with lags, causality, and a variety of other measurement problems discussed in previous papers mean that they are not as statistically robust as we would prefer. Furthermore they are offered as descriptive results rather than tests of an underlying behavioral model. Nonetheless they offer support for the hypothesis that the ability to access and interact with public sector research activity is an important determinant of the productivity of "downstream" private sector research. This effect is quite large: the estimated coefficients imply differences in research productivity of 30 to 40 percent between the most connected and least connected firms in the sample.

\section{Conclusions}

It is widely accepted that public sector research makes a significant contribution to growth by supplying basic, non-market oriented scientific knowledge that the private sector has weak incentives to produce. The precise mechanisms driving this effect are less well documented, and remain imperfectly 


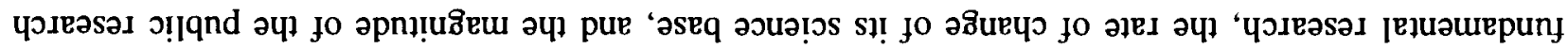

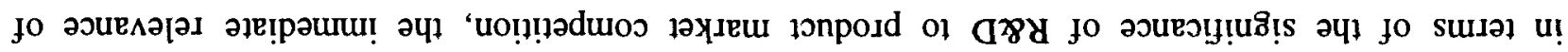

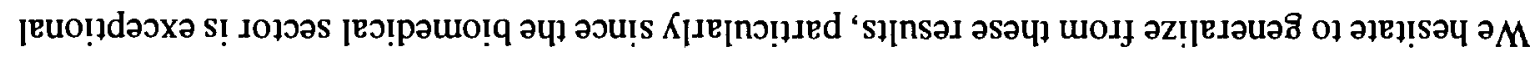

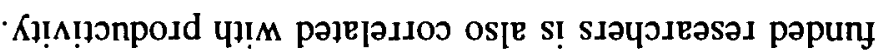

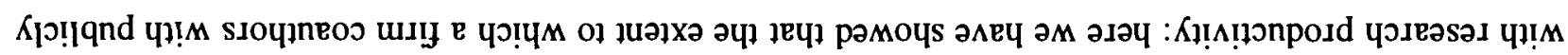

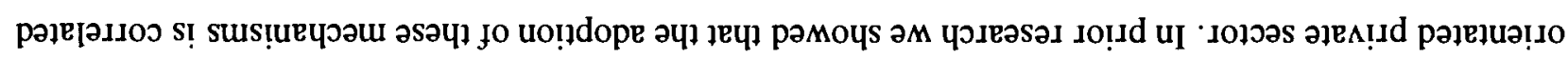

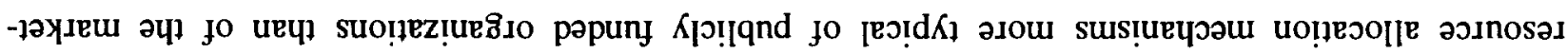

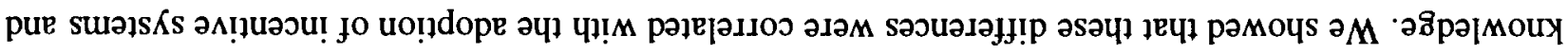

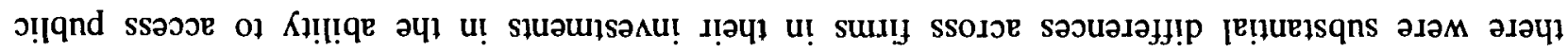

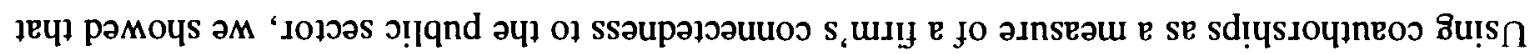

· \&u!unsuo?

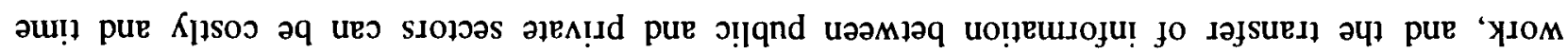

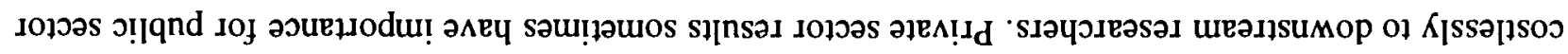

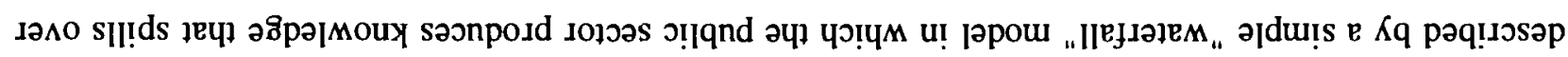

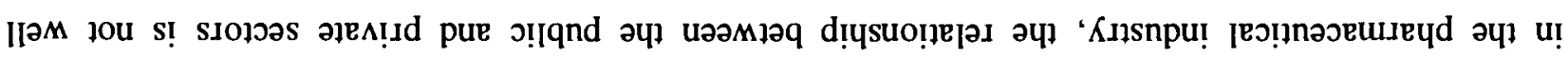

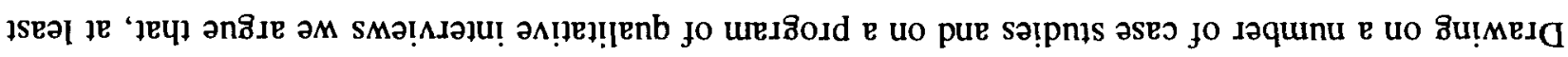

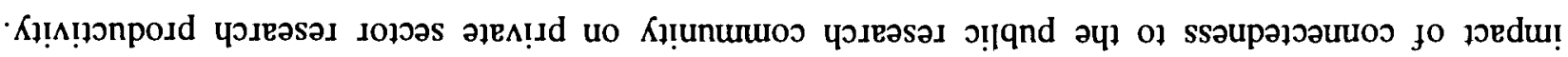

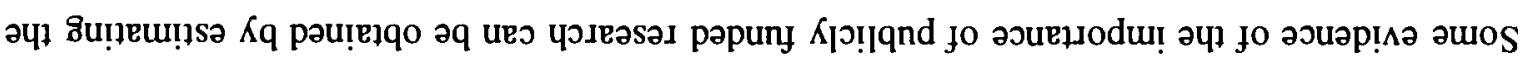

(966I 'IION pue uəuoJ

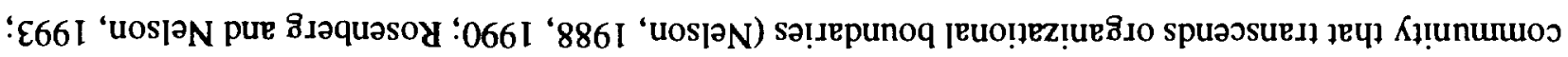

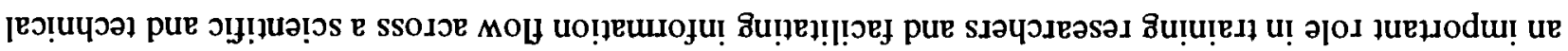

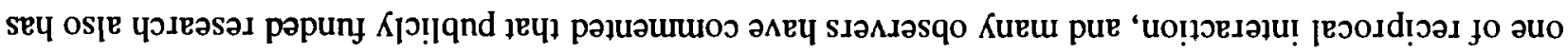

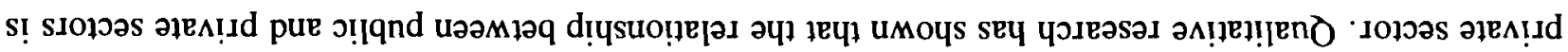

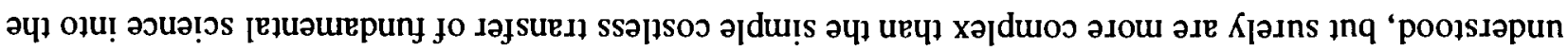


commitment. But we suspect that they may have relevance to other industries in which incumbent firms are grappling with the power of new technologies. From a private policy perspective, we believe that R\&D managers may have much more to learn from academic science than published research results, while scholarly understanding of growth may be enhanced by closer attention to the wider institutional setting of industrial R\&D, in particular the nature and extent of linkages to non-profit organizations.

The ability to "do good science" in the private sector may not be supportable in the long run without a close partnership with the institutions of open science. Policies which weaken these institutions, make public sector researchers more market-oriented, or redistribute rents through efforts to increase the appropriability of public research through restrictions in the ways in which public and private sectors work with each other may be therefore be counterproductive in the long run. Recent debate concerning the use of CRADAs (Cooperative Research and Development Agreements) and the pricing and production of Taxol is a case in point. ${ }^{18}$

${ }^{18}$ Hearing of the Regulation, Business Opportunity and Energy Subcommittee of the House Small Business Committee, January 25, 1993; Hearing of the Committee on Governmental Affairs, United States Senate, July 27, 1994. 


\section{References}

Adams, James (1990) "Fundamental Stocks of Knowledge and Productivity Growth", Journal of Political Economy, 98(4), pp673-702.

Aoki, Masahiko (1990) "Towards An Economic Model of the Japanese firm", Journal of Economic Literature, 28(1), pp 1-27.

Arrow, K. (1962) "Economic Welfare and the Allocation of Resources for Invention." in R. Nelson, ed. The Rate and Direction of Inventive Activity, Princeton: Princeton University Press, pp609-619.

Blumenthal, D. (1986) "Academic-Industry Relationships in the Life Sciences (Extent, Consequences, and Management)," JAMA, 268, pp3344-49.

Borel, J.F., Kis, Z.L., and Beveridge, T. (1995) "The History of the Discovery and Development of Cyclosporine" in V.J. Merluzzi and J. Adams (eds.) The Search for Anti-Inflammatory Drugs, Boston: Birkhauser.

Brown, M.S. \& Goldstein, J.L. 1986. "A receptor-mediated pathway for cholesterol homeostasis." Science, 212: 34-47.

Cockburn, Iain and Rebecca Henderson (1994) "Racing to Invest? The Dynamics of Competition in Ethical Drug Discovery", Journal of Economics and Management Strategy, 3(3), pp481-519.

Cockburn, Iain and Rebecca Henderson (1996) "Exploring Inertia: Complementarities and Firm Effects in Pharmaceutical Research, Mimeo, MIT April 1996.

Cohen, W.M. and Levinthal, D.A, (1989) "Innovation and Learning: The Two Faces of R\&D." Economic Journal, 99, pp569-596.

Cohen, Linda and Noll, Roger (1996) "Privatizing Public Research: the New Competitiveness Strategy" in R. Landau, T. Taylor, and G. Wright (eds) The Mosaic of Economic Growth, Stanford: 
Stanford University Press. pp305-334.

Comroe, Julius and Robert Dripps (1976) "Scientific Basis for the Support of Biomedical Research," Science, 192, p105.

Crane, D. (1972) Invisible College: Diffusion of Knowledge in Scientific Communities, Chicago, University of Chicago Press.

Dasgupta, Partha and Paul A. David (1987) "Information Disclosure and the Economics of Science and Technology." in G. R. Feiwel (ed.) Arrow and the Ascent of Modern Economic Theory, New York: NYU Press.

Dasgupta, P. and David, P. (1994) "Towards a New Economics of Science," Research Policy, 23, pp487-521.

David, Paul, David Mowery, and Edward Steinmuller (1992) "Analyzing the Economic Payoffs From Basic Research", Economics of Innovation and New Technologies, 2(4), pp73-90.

Gambardella, Alfonso (1992) "Competitive Advantage from in-house scientific research: The US pharmaceutical industry in the 1980s" Research Policy, XX, pp 1-17.

Gambardella, Alfonso (1995) Science and Innovation: the US Pharmaceutical Industry in the 1980s, Cambridge: Cambridge University Press.

Gannelin, C.R. "General Approaches to Discovering New Drugs" in Gannelin C.R. and S. M. Roberts (eds.) (1993) Medicinal Chemistry, 2nd Edition, London: Academic Press, p.121-140.)

Gilman, A., T. W. Rall, Alan Nies and Palmer Taylor (1993) Goodman and Gilman's The Pharmacological Basis of Therapeutics, 8th Edition. New York: McGraw-Hill.

Griliches, Zvi (1979) "Issues in Assessing the Contribution of Research and Development to Productivity Growth", Bell Journal of Economics, 10(1) pp 92-116. 
Griliches, Zvi (1994) "Productivity, R\&D and the Data Constraint", American Economic Review, 84(1), pp1-23.

Henderson, Rebecca (1994) "The Evolution of Integrative Competence: Innovation in Cardiovascular Drug Discovery", Industrial and Corporate Change, 3(3), pp 607-630.

Henderson, Rebecca and Iain Cockburn (1994) "Measuring Competence? Exploring Firm Effects in Pharmaceutical Research", Strategic Management Journal, 15, pp63-84.

Henderson, Rebecca and Cockburn, Iain (1996) "Scale, Scope and Spillovers: The Determinants of Research Productivity in Drug Discovery." RAND Journal of Economics, 27(1), pp32-59.

Hicks, Diana (1995) "Published Papers, Tacit Competencies and Corporate Management of the Public/Private Character of Knowledge." Industrial and Corporate Change, 4(2), pp401-424.

Jaffe, Adam (1989) "Real Effects of Academic Research", American Economic Review, 79(5), pp957970.

Jones, Charles and John Williams, (1995) "Too Much of a Good Thing? The Economics of Investment in R\&D" Stanford University Department of Economics Working Paper \#96-005.

Koenig, E. (1982) "A Bibiometric Analysis of Pharmaceutical Research", Research Policy, 12(1), pp1536

Liebskind, Julia Porter, Amalya Lumerman Oliver, Lynne Zucker and Marilyn Brewer (1995) "Social Networks, Learning, and Flexbility: Sourcing Scientific Knowledge in New Biotechnology Firms", NBER Working Paper No. 5320, November 1995.

Mansfield, Edwin (1991) "Academic Research and Industrial Innovation", Research Policy, 20(1), pp112.

Maxwell, Robert A. and Shohreh B. Eckhardt (1990) Drug Discovery: A Case Book and Analysis, 
Clifton, NJ: Humana Press.

Merton, D. (1973) in N.W. Starer (ed.) The Sociology of Science: Theoretical and Empirical Investigation, Chicago: University of Chicago Press.

Mowery, David (1983) "Economic Theory and Government Technology Policy", Policy Sciences, 16, pp 27-43.

Narin, Francis and D. Olivastro (1992) "Status Report - Linkage Between Technology and Science", Research Policy, 21(3), pp237-249

Nelson, Richard (1959) "The Simple Economics of Basic Scientific Research", Journal of Political Economy, 67(2), pp297-306.

Nelson, Richard (1988) "Institutions Supporting Technical Change in the United States", in Dosi et al. (eds) Technological Change and Economic Theory, London: Pinter.

Nelson, Richard (1990a) "Capitalism as an Engine of Progress", Research Policy, 19(3), pp193-214.

Nussbaum, Bruce (1990) Good Intentions: How Big Business and the Medical Establishment Are Corrupting the Fight Against AIDS, New York: Atlantic Monthly Press.

Office of Technology Assessment (1993) Pharmaceutical R\&D: Costs, Risks and Rewards, Washington DC: Office of Technology Assessment, United States Congress.

Ondetti M.A., Rubin B., and Cushman D.W.: (1977) "Design of specific inhibitors of angiotensinconverting enzyme. New class of orally effective antihypertensive agents." Science, 196, pp441444.

Penan, H. (1996) "R\&D Strategy in a Techno-economic network: Alzheimer's disease therapeutic strategies" Research Policy, Vol. 25, pp337-358. 
Raiten, Daniel and Berman, Stanley: "Can the Impact of Basic Biomedical Research be Measured? A Case Study Approach." August 1993. Working paper, Life Sciences Research Office, Federation of American Societies for Experimental Biology.

Richardson, K, K. Cooper, M.S. Marriott, M.H.Tarbit, P.F. Troke and P.J.Whittle: (1990) "Discovery of Fluconazole, a Novel Antifungal Agent" Review of Infectious Diseases, 12(3), ppS267-S271.

Rittmaster, Roger (1994) "Finasteride" The New England Journal of Medicine, January 13, 1994, pp120125.

Rosenberg, Nathan, (1990) "Why Do Firms Do Basic Research (With Their Own Money)", Research Policy, 19(3), pp165-174.

Rosenberg, Nathan, and Richard Nelson (1993) "American Universities and Technical Advance in Industry", CEPR Working Paper \#342, Stanford University.

Shapiro, D.J. and Rodwell, V.W. (1971) "Regulation of Hepatic 3-Hydroxy-3-methylglutaryl Coenzyme A Reductase and Cholesterol Synthesis", Journal of Biological Chemistry, (1971), 246(10), pp. $3210-3216$.

Siperstein, M.D. and Guest, M.J., (1959) "Studies on the Site of the Feedback Control of Cholesterol Synthesis", Working Paper, Department of Internal Medicine, The University of Texas Southwestern Medical School, Dallas, TX.

Stephan, Paula (1995) An Essay on the Economics of Science, Journal of Economic Literature (Forthcoming)

Ward, Michael and Dranove, David (1995) "The Vertical Chain of R\&D in the Pharmaceutical Industry." Economic Inquiry, 33, pp1-18.

Wurtman, Richard J. and Robert L. Bettiker (1994) "How to Find a Treatment for Alzheimer's Disease" Neurobiology of Aging, 15, pp S1-S3. 
Wurtman, Richard J. and Robert L. Bettiker (1996) "Training the Students who will Discover Treatments for Psychiatric Diseases" Psychiatric Research Report, Spring 1996.

Zucker, Lynne, Michael Darby and Marilynn Brewer (1997) "Intellectual Capital and The Birth of U.S. Biotechnology Enterprises", American Economic Review, 87(3) pp.xxx-xxxx

Zucker, Lynne, Michael Darby, and Jerry Armstrong (1994) "Intellectual Capital and the Firm: the Technology of Geographically Localized Knowledge Spillovers", NBER Working Paper No. 4946, December 1994.

Zucker Lynne and Michael Darby (1995) "Virtuous Circles of Productivity: Star Bioscientists and the Institutional Transformation of Industry", NBER Working Paper No. 5342, November 1995. 


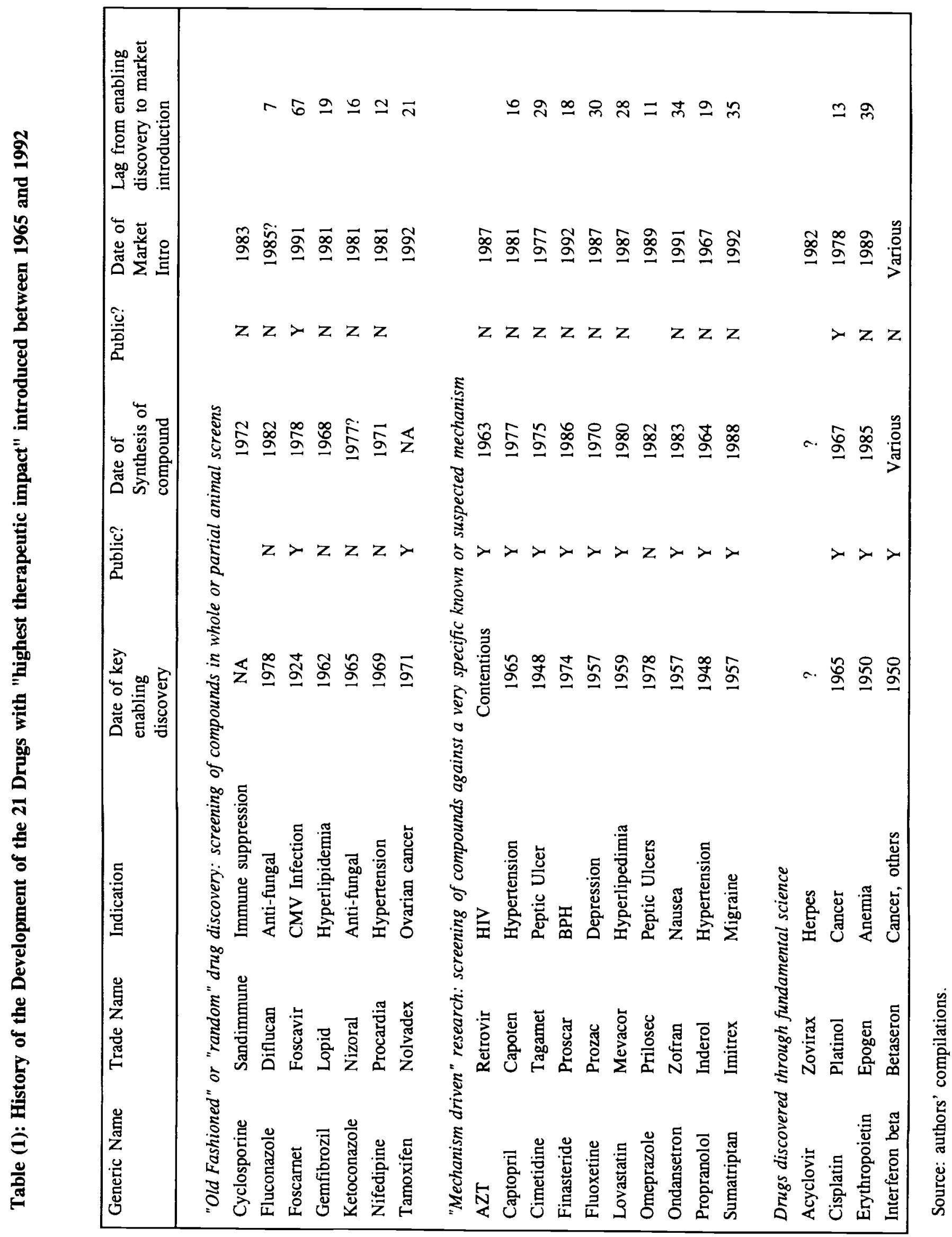


Table (2): Definitions of Coauthor Type

\begin{tabular}{|l|l|l|}
\hline TYPE & Definition & Examples \\
\hline SELF & $\begin{array}{l}\text { "COMPANY X" in file obtained by searching } \\
\text { Science Citation Index for "COMPANY X" }\end{array}$ & \\
\hline HOSPITAL & Hospitals, clinics, treatment centers & $\begin{array}{l}\text { Mayo Clinic, Hammersmith Hospital, Hôpital Hotel } \\
\text { Dieu, Veterans Administration Medical Center }\end{array}$ \\
\hline NIH & Any of National Institutes of Health & $\begin{array}{l}\text { National Cancer Institute, National Institute of Allergy } \\
\text { and Infectious Diseases, National Eye Institute }\end{array}$ \\
\hline PUBLIC & Govt affiliated organizations, excluding NIH. & $\begin{array}{l}\text { FDA, USDA Agricultural Research Service, Medical } \\
\text { Research Council, New York State Dept of Public } \\
\text { Health, CNRS, US Navy, Institut Pasteur }\end{array}$ \\
\hline UNIVERSITY & $\begin{array}{l}\text { Universities and medical schools (including } \\
\text { university hospitals) }\end{array}$ & $\begin{array}{l}\text { University of Michigan, ETH Zurich, Harvard Medical } \\
\text { School, University of Texas, Chinese Academy of } \\
\text { Sciences }\end{array}$ \\
\hline PRIVATE & $\begin{array}{l}\text { For-profit organizations, principally } \\
\text { pharmaceutical and biomedical firms }\end{array}$ & $\begin{array}{l}\text { Pfizer, ICI, Boehringer Ingelheim, BASF, Genentech, } \\
\text { SRI International, IBM, Meiji Seika Kaisha Inc }\end{array}$ \\
\hline NON-PROFIT & $\begin{array}{l}\text { Non-profit non-govt organizations e.g. } \\
\text { Imperial Cancer Research Fund }\end{array}$ & $\begin{array}{l}\text { Imperial Cancer Research Fund, Salk Institute, } \\
\text { Oklahoma Medical Research Foundation }\end{array}$ \\
\hline UNCLASSFIED & Unclassified & "c/o Gibson JR", GBF, Dept Med, Flow Labs \\
\hline
\end{tabular}

Table (3) Sample Source Record

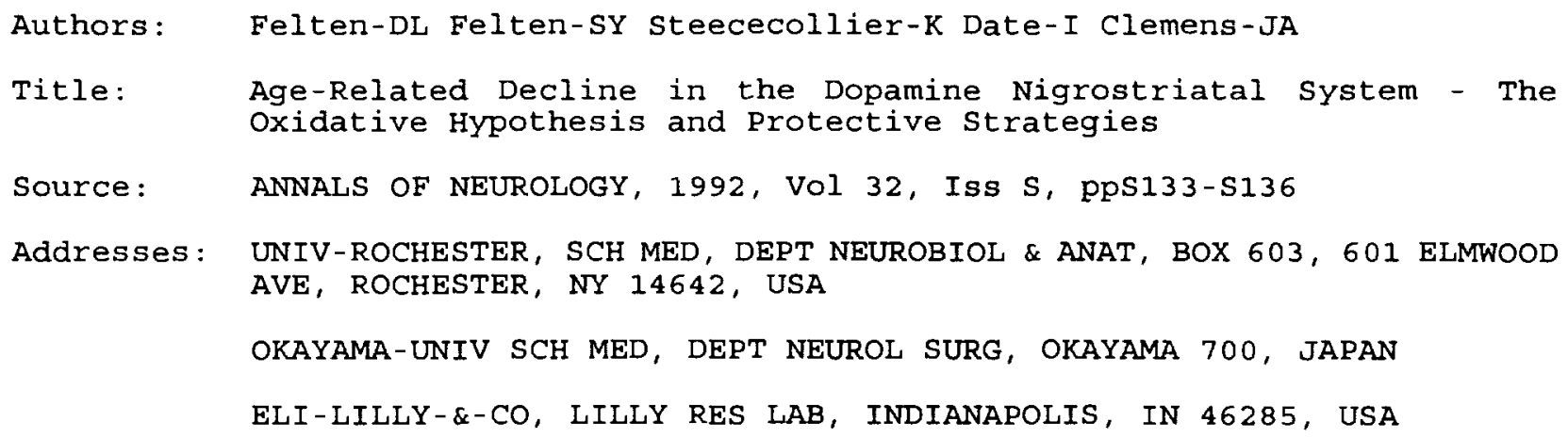


Table (4) Changes in Pattern of Coauthorship Over Time

The first column identifies years. The second column gives the total number of papers published by 20 sample firms in each year that appear in Science Citation Index 1980-1994. The third column gives the total number of coauthorships in each year by these firms. Entries in the rest of the table are the fraction of total coauthorships by the sample firms with different categories of coauthoring institution.

\begin{tabular}{|c|c|c|ccccccccc|}
\hline Year & $\begin{array}{l}\text { Total } \\
\text { papers } \\
\text { published }\end{array}$ & $\begin{array}{l}\text { Total } \\
\text { coauthor } \\
\text {-ships }\end{array}$ & SELF & Hospitals & Public & Private & $\begin{array}{l}\text { Non- } \\
\text { profit }\end{array}$ & $\begin{array}{l}\text { Univer } \\
\text {-sities }\end{array}$ & NIH & $\begin{array}{l}\text { Unclass } \\
\text {-ified }\end{array}$ \\
\hline 80 & 3015 & 3413 & 0.62 & 0.06 & 0.03 & 0.02 & 0.02 & 0.24 & 0.01 & 0.01 \\
81 & 2888 & 3276 & 0.60 & 0.07 & 0.02 & 0.03 & 0.02 & 0.25 & 0.01 & 0.01 \\
82 & 3097 & 3781 & 0.52 & 0.08 & 0.03 & 0.03 & 0.02 & 0.31 & 0.02 & 0.01 \\
83 & 3379 & 4145 & 0.50 & 0.10 & 0.03 & 0.03 & 0.02 & 0.29 & 0.02 & 0.01 \\
84 & 3216 & 3933 & 0.49 & 0.10 & 0.03 & 0.04 & 0.02 & 0.29 & 0.01 & 0.01 \\
85 & 4032 & 4845 & 0.49 & 0.10 & 0.03 & 0.04 & 0.02 & 0.30 & 0.01 & 0.01 \\
86 & 4056 & 5048 & 0.45 & 0.10 & 0.03 & 0.04 & 0.02 & 0.33 & 0.01 & 0.01 \\
87 & 4496 & 5704 & 0.45 & 0.09 & 0.04 & 0.04 & 0.03 & 0.33 & 0.01 & 0.01 \\
88 & 4427 & 5717 & 0.44 & 0.09 & 0.03 & 0.04 & 0.03 & 0.34 & 0.02 & 0.01 \\
89 & 4277 & 5573 & 0.42 & 0.09 & 0.03 & 0.04 & 0.02 & 0.36 & 0.01 & 0.01 \\
90 & 5029 & 6734 & 0.41 & 0.09 & 0.03 & 0.05 & 0.03 & 0.36 & 0.02 & 0.01 \\
91 & 5457 & 7624 & 0.38 & 0.09 & 0.04 & 0.07 & 0.03 & 0.38 & 0.01 & 0.01 \\
92 & 6639 & 9303 & 0.37 & 0.09 & 0.04 & 0.07 & 0.03 & 0.37 & 0.01 & 0.01 \\
93 & 7005 & 9994 & 0.35 & 0.10 & 0.03 & 0.07 & 0.03 & 0.38 & 0.01 & 0.02 \\
94 & 7173 & 10198 & 0.35 & 0.09 & 0.03 & 0.07 & 0.03 & 0.38 & 0.02 & 0.02 \\
\hline
\end{tabular}

Source: Science Citation Index, various years, authors computations'. 
Table (5) Patterns of Coauthorship by TYPE of Coauthor and Firm

The first column identifies sample firms. The second column gives the total number of papers published by that firm appearing in Science Citation Index 1980-1994. The third column gives the total number of coauthorships by each firm. Entries in the rest of the table are the fraction of total coauthorships by each firm with different categories of coauthoring institution.

\begin{tabular}{|c|c|c|c|c|c|c|c|c|c|c|}
\hline \multirow[b]{2}{*}{ FIRM } & \multirow{2}{*}{$\begin{array}{l}\text { Number } \\
\text { of } \\
\text { papers }\end{array}$} & \multirow{2}{*}{$\begin{array}{l}\text { Number of } \\
\text { coauthor- } \\
\text { ships }\end{array}$} & \multicolumn{8}{|c|}{ Fraction of coauthorships with: } \\
\hline & & & SELF & Hospitals & Public & Private & $\begin{array}{l}\text { Non- } \\
\text { Profit }\end{array}$ & $\begin{array}{l}\text { Univer } \\
\text {-sities }\end{array}$ & $\mathrm{NIH}$ & $\begin{array}{l}\text { Unclass- } \\
\text { ified }\end{array}$ \\
\hline Abbott & 3410 & 4894 & 0.40 & 0.10 & 0.04 & 0.04 & 0.03 & 0.36 & 0.02 & 0.01 \\
\hline Beecham & 1139 & 1286 & 0.63 & 0.09 & 0.02 & 0.02 & 0.02 & 0.21 & 0.00 & 0.01 \\
\hline Bristol-Myers & 4115 & 6177 & 0.37 & 0.10 & 0.03 & 0.06 & 0.02 & 0.39 & 0.02 & 0.01 \\
\hline Ciba Geigy & 7656 & 10114 & 0.43 & 0.08 & 0.04 & 0.06 & 0.04 & 0.32 & 0.00 & 0.02 \\
\hline Fujisawa & 1012 & 1159 & 0.62 & 0.04 & 0.02 & 0.04 & 0.00 & 0.27 & 0.00 & 0.01 \\
\hline Glaxo & 3944 & 5517 & 0.33 & 0.14 & 0.02 & 0.06 & 0.02 & 0.41 & 0.01 & 0.02 \\
\hline Hoechst & 3763 & 4900 & 0.41 & 0.07 & 0.03 & 0.10 & 0.04 & 0.32 & 0.00 & 0.03 \\
\hline Hoffman LR & 4137 & 6061 & 0.32 & 0.09 & 0.04 & 0.05 & 0.03 & 0.41 & 0.05 & 0.01 \\
\hline Lilly & 4761 & 6115 & 0.50 & 0.08 & 0.02 & 0.04 & 0.01 & 0.33 & 0.01 & 0.01 \\
\hline Merck & 9291 & 11912 & 0.48 & 0.08 & 0.03 & 0.04 & 0.02 & 0.32 & 0.02 & 0.01 \\
\hline Nor. Eaton & 232 & 262 & 0.63 & 0.05 & 0.01 & 0.07 & 0.00 & 0.23 & 0.00 & 0.01 \\
\hline Pfizer & 2963 & 3927 & 0.42 & 0.08 & 0.02 & 0.07 & 0.02 & 0.36 & 0.01 & 0.02 \\
\hline Sankyo & 1050 & 1133 & 0.68 & 0.01 & 0.02 & 0.03 & 0.01 & 0.25 & 0.00 & 0.00 \\
\hline Searle & 1170 & 1573 & 0.38 & 0.05 & 0.02 & 0.05 & 0.02 & 0.46 & 0.01 & 0.00 \\
\hline Smithkline & 3470 & 4766 & 0.40 & 0.08 & 0.05 & 0.07 & 0.03 & 0.35 & 0.01 & 0.01 \\
\hline Squibb & 899 & 1071 & 0.58 & 0.11 & 0.01 & 0.03 & 0.00 & 0.25 & 0.00 & 0.01 \\
\hline Takeda & 1793 & 2263 & 0.52 & 0.06 & 0.02 & 0.02 & 0.01 & 0.35 & 0.00 & 0.01 \\
\hline Upjohn & 4982 & 6733 & 0.43 & 0.06 & 0.02 & 0.04 & 0.02 & 0.42 & 0.02 & 0.01 \\
\hline Wellcome & 7840 & 11780 & 0.31 & 0.11 & 0.04 & 0.03 & 0.04 & 0.45 & 0.01 & 0.01 \\
\hline Yamanouchi & 559 & 624 & 0.57 & 0.05 & 0.02 & 0.04 & 0.02 & 0.30 & 0.00 & 0.00 \\
\hline NIH & 81574 & 112338 & 0.39 & 0.08 & 0.08 & 0.04 & 0.04 & 0.37 & 0.00 & 0.01 \\
\hline
\end{tabular}

Source: Science Citation Index, various years, authors' computations. 
Table (6): Multinomial logit coefficients

Dependent variable: TYPE of coauthor institution

Subsample of 10 firms, 1980-1988 data: 26501 observations

\begin{tabular}{|l|ccccc|}
\hline & \multicolumn{5}{|c|}{ Explanatory Variables } \\
$\begin{array}{l}\text { Category: } \\
\text { TYPE of coauthor } \\
\text { institution }\end{array}$ & $\begin{array}{l}\text { Time } \\
\text { Trend }\end{array}$ & $\begin{array}{l}\text { Degree to which } \\
\text { firm is "pro- } \\
\text { publication" }\end{array}$ & $\begin{array}{l}\text { Degree to which } \\
\text { decisions are made } \\
\text { by "dictator" }\end{array}$ & $\begin{array}{l}\text { Size of firm's } \\
\text { drug discovery } \\
\text { effort in \$m }\end{array}$ & Constant \\
\hline HOSPITAL & 0.029 & 0.009 & 0.059 & $-0.008^{* * *}$ & -1.220 \\
NON-PROFIT & $(0.023)$ & $(0.044)$ & $(0.038)$ & $(0.002)$ & $(1.783)$ \\
PUBLIC incl & 0.001 & $0.176^{* *}$ & 0.075 & $-0.011^{* *}$ & -0.726 \\
NIH & $(0.027)$ & $(0.061)$ & $(0.049)$ & $(0.002)$ & $(2.275)$ \\
SELF & $-0.066^{* *}$ & $0.313^{* *}$ & -0.103 & $-0.006^{* *}$ & $5.155^{* *}$ \\
& $(0.022)$ & $(0.053)$ & $(0.041)$ & $(0.002)$ & $(1.838)$ \\
UNIVERSITY & $-0.062^{* *}$ & $-0.131^{* *}$ & $0.163^{* *}$ & $-0.003^{* *}$ & $8.089^{* *}$ \\
& $(0.018)$ & $(0.040)$ & $(0.034)$ & $(0.001)$ & $(1.526)$ \\
& 0.014 & $0.078^{* *}$ & $0.085^{* *}$ & $-0.008^{* *}$ & 1.018 \\
\hline
\end{tabular}

Notes: Reference category: PRIVATE. BHHH standard errors in parentheses. Log-likelihood function=-24987. Restricted $\log$-likelihood function $=-25317$.

Marginal Effects (in percent) at the sample mean on probability of coauthoring with:

\begin{tabular}{|l|cccc|}
\hline & \multicolumn{4}{|c|}{ Explanatory Variables } \\
$\begin{array}{l}\text { Category: } \\
\text { TYPE of coauthor } \\
\text { institution }\end{array}$ & $\begin{array}{l}\text { Time } \\
\text { Trend }\end{array}$ & $\begin{array}{l}\text { Degree to which } \\
\text { firm is "pro- } \\
\text { publication" }\end{array}$ & $\begin{array}{l}\text { Degree to which } \\
\text { R\&D decisions are } \\
\text { made by "dictator" }\end{array}$ & $\begin{array}{l}\text { Size of firm's } \\
\text { drug discovery } \\
\text { effort in } \$ \mathrm{~m}\end{array}$ \\
\hline PRIVATE & 0.078 & 0.038 & $-0.035^{* *}$ & $0.017^{* *}$ \\
HOSPITAL & $0.516^{* *}$ & 0.185 & $-0.486^{* *}$ & $-0.026^{* *}$ \\
NON-PROFIT & 0.059 & $0.446^{* *}$ & -0.082 & $-0.015^{* *}$ \\
PUBLIC incl NIH & $-0.224^{* *}$ & $1.739^{* *}$ & $-0.645^{* *}$ & -0.001 \\
SELF & $-1.719^{* *}$ & $-5.443^{* *}$ & $2.409^{* *}$ & $0.011^{* *}$ \\
UNIVERSITY & $1.292^{* *}$ & $3.040^{* *}$ & $-0.850^{* *}$ & $-0.001^{* * *}$ \\
\hline Sample means of covariates & 84.99 & 4.05 & 3.08 & 50.57 \\
\hline
\end{tabular}

** indicates significant at $5 \%$ level " indicates significant at $10 \%$ level

Source: authors' computations. 
Table (7): Determinants of research productivity.

OLS Regression. Dependent variable: Important Patents per research dollar Subsample of 10 firms 1980-1988 data, 84 observations.

\begin{tabular}{|c|c|c|c|c|c|c|}
\hline & (1) & (2) & (3) & (4) & (5) & (6) \\
\hline Intercept & $\begin{array}{l}5.159^{* *} \\
(1.032)\end{array}$ & $\begin{array}{l}5.292^{* *} \\
(1.042)\end{array}$ & $\begin{array}{l}4.252^{* *} \\
(0.859)\end{array}$ & $\begin{array}{l}4.037^{* *} \\
(0.839)\end{array}$ & $\begin{array}{l}3.275^{* *} \\
(1.026)\end{array}$ & $\begin{array}{c}1.784 \\
(1.220)\end{array}$ \\
\hline $\begin{array}{l}\text { Fraction of coauthorships with } \\
\text { universities }\end{array}$ & $\begin{array}{l}7.340^{* *} \\
(1.611)\end{array}$ & $\begin{array}{l}6.897^{* *} \\
(1.680)\end{array}$ & $\begin{array}{l}5.137^{* *} \\
(1.789)\end{array}$ & $\begin{array}{l}4.493^{* *} \\
(1.759)\end{array}$ & $\begin{array}{l}5.381^{* *} \\
(1.661)\end{array}$ & $\begin{array}{c}1.111 \\
(1.711)\end{array}$ \\
\hline Papers per research dollar & & $\begin{array}{c}0.005 \\
(0.006)\end{array}$ & & $\begin{array}{l}0.061^{* *} \\
(0.026)\end{array}$ & $\begin{array}{c}0.003 \\
(0.005)\end{array}$ & $\begin{array}{c}0.027 \\
(0.024)\end{array}$ \\
\hline $\begin{array}{l}\text { SCOPE: Number of substantial } \\
\text { research programs }\end{array}$ & & & & & $\begin{array}{c}0.100 \\
(0.135)\end{array}$ & $\begin{array}{l}-0.354^{*} \\
(0.159)\end{array}$ \\
\hline SCOPE-squared & & & & & $\begin{array}{l}-0.005 \\
(0.006)\end{array}$ & $\begin{array}{c}0.012 \\
(0.009)\end{array}$ \\
\hline $\begin{array}{l}\text { SCALE: Total research } \\
\text { spending }\end{array}$ & & & & & $\begin{array}{l}-0.012 \\
(0.007)\end{array}$ & $\begin{array}{l}-0.023 \\
(0.013)\end{array}$ \\
\hline Stock of past patents & & & & & $\begin{array}{l}0.003^{* *} \\
(0.001)\end{array}$ & $\begin{array}{l}0.010^{* *} \\
(0.003)\end{array}$ \\
\hline FIRM DUMMIES & & & YES & YES & & YES \\
\hline TIME TREND & $\begin{array}{l}-0.227^{* *} \\
(0.045)\end{array}$ & $\begin{array}{l}-0.231^{* *} \\
(0.045)\end{array}$ & $\begin{array}{l}-0.203^{* *} \\
(0.038)\end{array}$ & $\begin{array}{l}-0.211^{* *} \\
(0.037)\end{array}$ & $\begin{array}{l}-0.154^{* *} \\
(0.045)\end{array}$ & $\begin{array}{r}-0.010 \\
(0.056)\end{array}$ \\
\hline RMSE & 0.987 & 0.987 & 0.777 & 0.754 & 0.840 & 0.656 \\
\hline R-squared & 0.293 & 0.301 & 0.611 & 0.638 & 0.519 & 0.742 \\
\hline
\end{tabular}

Standard errors in parentheses

* indicates significant at $5 \%$ level

* indicates significant at $10 \%$ level

Source: authors' computations. 
Table (8): Determinants of research productivity.

OLS Regression. Dependent variable: Important Patents per research dollar Subsample of 10 firms 1980-1988 data, 84 observations.

\begin{tabular}{|c|c|c|c|c|c|c|}
\hline & (1) & (2) & (3) & (4) & (5) & (6) \\
\hline Intercept & $\begin{array}{l}4.043^{* *} \\
(1.358)\end{array}$ & $\begin{array}{l}2.380^{* *} \\
(1.198)\end{array}$ & $\begin{array}{l}2.551^{* *} \\
(1.146)\end{array}$ & $\begin{array}{l}2.515^{* *} \\
(1.118)\end{array}$ & $\begin{array}{c}2.338 \\
(1.205)\end{array}$ & $\begin{array}{c}0.601 \\
(1.383)\end{array}$ \\
\hline $\begin{array}{l}\text { Fraction of publications by } \\
\text { top } 10 \text { authors }\end{array}$ & $\begin{array}{c}2.052 \\
(1.489)\end{array}$ & $\begin{array}{l}3.897^{* *} \\
(1.717)\end{array}$ & $\begin{array}{l}3.358^{* *} \\
(1.646)\end{array}$ & $\begin{array}{l}3.236^{* *} \\
(1.613)\end{array}$ & $\begin{array}{c}1.933 \\
(1.327)\end{array}$ & $\begin{array}{c}2.526 \\
(1.461)\end{array}$ \\
\hline $\begin{array}{l}\text { Fraction of coauthorships with } \\
\text { universities }\end{array}$ & & & $\begin{array}{l}4.870^{* *} \\
(1.749)\end{array}$ & $\begin{array}{l}4.305^{* *} \\
(1.726)\end{array}$ & $\begin{array}{l}5.873^{* *} \\
(1.683)\end{array}$ & $\begin{array}{c}0.955 \\
(1.688)\end{array}$ \\
\hline Papers per research dollar & & & & $\begin{array}{l}0.056^{* *} \\
(0.002)\end{array}$ & $\begin{array}{c}0.005 \\
(0.005)\end{array}$ & $\begin{array}{c}0.028 \\
(0.024)\end{array}$ \\
\hline $\begin{array}{l}\text { SCOPE: number of substantial } \\
\text { research programs }\end{array}$ & & & & & $\begin{array}{c}0.151 \\
(0.138)\end{array}$ & $\begin{array}{l}-0.319^{*} \\
(0.158)\end{array}$ \\
\hline SCOPE-squared & & & & & $\begin{array}{l}-0.009 \\
(0.007)\end{array}$ & $\begin{array}{c}0.011 \\
(0.009)\end{array}$ \\
\hline $\begin{array}{l}\text { SCALE: total research } \\
\text { spending }\end{array}$ & & & & & $\begin{array}{l}-0.007 \\
(0.008)\end{array}$ & $\begin{array}{l}-0.025^{*} \\
(0.013)\end{array}$ \\
\hline Stock of past patents & & & & & $\begin{array}{l}0.003^{* *} \\
(0.001)\end{array}$ & $\begin{array}{l}0.009^{* *} \\
(0.003)\end{array}$ \\
\hline FIRM DUMMIES & & YES & YES & YES & & YES \\
\hline TIME TREND & $\begin{array}{l}-0.142^{* *} \\
(0.048)\end{array}$ & $\begin{array}{l}-0.129^{* *} \\
(0.036)\end{array}$ & $\begin{array}{l}-0.179^{* * *} \\
(0.039)\end{array}$ & $\begin{array}{l}-0.187^{* *} \\
(0.038)\end{array}$ & $\begin{array}{l}-0.163^{* *} \\
(0.045)\end{array}$ & $\begin{array}{c}0.006 \\
(0.055)\end{array}$ \\
\hline RMSE & 1.093 & 0.792 & 0.757 & 0.738 & 0.834 & 0.646 \\
\hline R-squared & 0.132 & 0.595 & 0.635 & 0.658 & 0.532 & 0.753 \\
\hline
\end{tabular}

Standard errors in parentheses

** indicates significant at $5 \%$ level

- indicates significant at $10 \%$ level

Source: authors' computations. 
Figure (1)

Papers published about Prozac

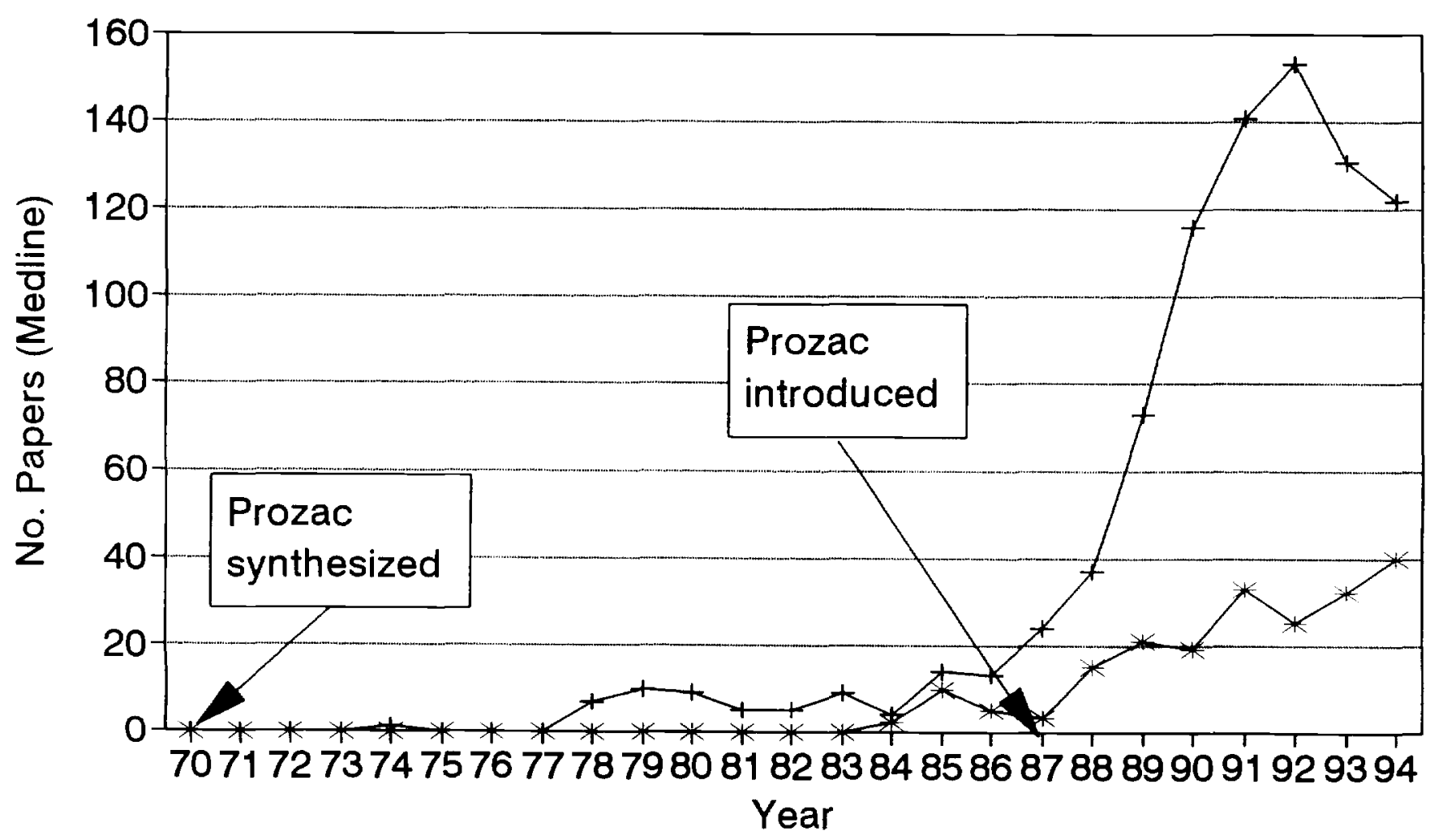

+ Research $*$ Clinical 